also made on the proposal to erect a steel latticetower $150 \mathrm{ft}$. high for a police radio transmitter and on the continuance of threats from opencast coalmining, notably at Barlow. However, the arrangement between the General Post Office and the Peak Park Planning Board covering the whole Peak regarding proposals likely to affect the landscape, and of the Sheffield Corporation's policy towards tree planting, receive favourable mention.

\section{International Certification of Herbage Seed}

As a result of a certification scheme introduced by the Organization for European Economic Co-operation, the farmers of Europe will in future be able to rely on the qualities and types of seed for grasses and legumes offered for sale. In the past, confusion has arisen due to differences in nomenclature and methods of certification between countries. Hitherto, herbage seed offered in international trade has fallen into two eategories: uncertified seed and seed certified in accordance with various national systems. The effect of the new rules and directions approved by the Organization for European Economic Co-operation is the introduction of a third category-herbage seed bearing an international certificate and a special label issued under the authority of the official seedcertifying agencies in member countries of the Organization. The scheme is open to any of the seventeen member countries and will operate for an initial period of five years. Copies of the rules and directions can be obtained from the Director of Agriculture and Food of the Organization for European Economic Co-operation.

\section{Colleges of Technology in Britain}

IN a written answer in the House of Commons on June 18, the Minister of Education, Mr. Geoffrey Lloyd, listed the following colleges as approved, up to the present, as colleges of advanced technology : Birmingham College of Technology ; Bradford Institute of Technology ; Battersea College of Technology; Chelsea College of Science and Technology; Northampton College of Advanced Technology; Loughborough College of Technology; Salford Royal Technical College, and the Welsh College of Advanced Technology, Cardiff. Those approved as regional colleges are: Brighton Technical College; Bristol College of Technology ; Brunel College of Technology, Acton; City of Liverpool College of Building and City of Liverpool College of Technology ; Glamorgan College of Technology, Treforest; Huddersfield College of Technology ; Kingston-upon-Thames Technical College; Leicester College of Technology and Commerce; North Staffordshire Technical College, Stoke-upon-Trent; Nottingham and District Technical College; Plymouth and Devonport Technical College ; Portsmouth College of Technology ; Rugby College of Technology and Arts ; Sunderland Technical College; West Ham College of Technology ; and in London, the Borough Polytechnic, Southwark; Brixton L.C.C. School of Building, Lambeth; Northern Polytechnic, Islington; Sir John Cass College; The Polytechnic, St. Marylebone, and Woolwich Polytechnic.

\section{Imperial Cancer Research Fund}

THE fifty-fifth annual report of the Imperial Cancer Research Fund for 1956-57 (pp. 45. London : Imperial Cancer Research Fund, 1958), besides its survey of current work, refers to the approval of plans to build in Lincoln's Inn Fields, London, new and adequate laboratories adjoining the Royal College of Surgeons. The initial building costs are estimated at $£ 600,000$, and about $£ 250,000$ will be required for furnishing and equipping the laboratories, with an additional annual $£ 150,000$ for maintenance. The now research laboratories will provide accommodation for the chemico-pathological research at present being carried out at No. 48 Lincoln's Inn Fields, but will also permit a big expansion in the research pro. gramme of the Fund. Current work at Lincoln's Inn Fields is concerned mainly with the relation between hormones and human cancer, concentrating on cancer of the breast and of the prostate. An important part of the service there is the work on the early diagnosis of cancer by the study of smears of secretions. At the Mill Hill Laboratories fundamental biological research is largely concerned with tumour growth in animals and the characteristics of various malignant tumours. Dr. J. Craigie has perfected a method for storing tumours in a frozen state at $-32^{\circ} \mathrm{C}$. for four to seven years, and human tumours, removed at operations or at post-mortem examinations, are being transplanted into laboratory animals so that the effect of different agents on cell growth can be observed. The reaction of tumour cells to changes in environment is being studied with an ingenious kine. microscope with 'Perspex' observation chambers. Lists of papers published from the Laboratories since the last annual report are included in Dr. Craigie's and Prof. G. Hadfield's reports on the work of the Laboratories.

\section{Soviet Crystallographic Meeting}

The sixth general meeting called by the Commission for X-ray Diffraction of the Academy of Sciences of the U.S.S.R. was held in Leningrad during June 23-29. Some 900 people, including ten foreign guests, attended the opening session, which was addressed by the chairman of the Commission, Prof. G. S. Zhdanov (Moscow). The meeting proceeded in seven sections devoted to the X-ray study of alloys; X-ray studies of deformed metals; X-ray structural analysis and crystal chemistry ; apparatus and methods of X-ray structural analysis; $\mathrm{X}$-ray spectroscopy ; electronography ; and X-ray and $\gamma$-ray defectoscopy. The total number of papers contributed in these specialized sections was 333 , and in addition there were twelve contributions during the full sessions. The rapid growth of erystallographic research in the Soviet Union is evident from this meeting, and from the reported production of sealed $\mathrm{X}$-ray tubes in the U.S.S.R., namely, 3,887 tubes in 1957 and 4,700 in 1958. After the meeting most of the foreign guests travelled to Moscow and had opportunities of seeing the crystallographic work in progress in various institutes.

\section{Travelling Fellowship and Student Prizes in Psychiatry}

Mr. J. A. BALDwin, a medical student at the University of Aberdeen, has recently been awarded the first of the Mental Health Research Fund Travelling Fellowships. These are awarded annually to medical students, selected by an essay competition and interview, by the Mental Health Research Fund (39 Queen Anne Street, London, W.1), for special training in psychiatric or other departments abroad for six months. The Fund hopes in this way to stimulate interest in mental health and, particularly, 